\title{
An Ecological and Economic Assessment of the Nontimber Forest Product Gaharu Wood in Gunung Palung National Park, West Kalimantan, Indonesia
}

\author{
GARY D. PAOLI, ${ }^{*}$ DAVID R. PEART,$\uparrow$ MARK LEIGHTON,$\neq$ AND \\ ISMAYADI SAMSOEDINS \\ *Department of Ecology and Evolutionary Biology, University of Michigan, Ann Arbor, MI 48109, U.S.A., \\ email gpaoli@umich.edu or hancur_lagi@yahoo.com \\ †Department of Biology, Dartmouth College, Hanover, NH 03755, U.S.A. \\ $\ddagger$ Department of Anthropology \& Peabody Museum, Harvard University, 11 Divinity Avenue, Cambridge, MA \\ 02138, U.S.A. \\ §Forestry Research \& Development Center, Jl. Gunung Batu No. 5, Bogor 16610, Indonesia
}

\begin{abstract}
Ecological and economic data are essential to the identification of tropical nontimber forest products with the potential for sustainable and profitable extraction in a managed system. We studied the demographic effect and economic returns of harvesting aromatic gabaru wood from fungus-infected trees of Aquilaria malaccensis Lam. at Gunung Palung National Park, Indonesia, to evaluate the management potential of gabaru wood. Aquilaria malaccensis trees of $>20 \mathrm{~cm}$ in diameter occurred at low preharvest densities (0.16$0.32 \mathrm{ba}$ ) but were distributed across five of six forest types surveyed. During a recent harvest, $75 \%$ of trees were felled, with harvest intensities ranging from 50\% to 100\% among forest types. Overall, 50\% of trees contained gabaru wood, but trees at higher elevations contained gabaru wood more frequently (73\%) than trees at lower elevation (27\%). The mean density of regeneration (juveniles $>15 \mathrm{~cm}$ in height) near adult trees (3-7 $\mathrm{m}$ away) was $0.2 / \mathrm{m}^{2}, 200$ times greater than at random in the forest (10/ha), but long-term data on growth and survivorship are needed to determine whether regeneration is sufficient for population recovery. Gabaru wood extraction from Gunung Palung was very profitable for collectors, generating an estimated gross financial return per day of US $\$ 8.80$, triple the mean village wage. Yet, the estimated sustainable harvest of gaharu wood at natural tree densities generates a mean net present value of only $\$ 10.83 / \mathrm{ha}$, much lower than that of commercial timber harvesting, the dominant forest use in Kalimantan. Returns per unit area could be improved substantially, bowever, by implementing known silvicultural methods to increase tree densities, increase the proportion of trees that produce gaharu wood, and shorten the time interval between successive harvests. The economic potential of gaharu wood is unusual among nontimber forest products and justifies experimental trials to develop small-scale cultivation methods.
\end{abstract}

Evaluación Ecológica y Económica de la Madera Gaharu, un Producto Forestal No Maderable, en el Parque Nacional Gunung Palung, Kalimantan Occidental, Indonesia

Resumen: Datos ecológicos y económicos son esenciales para la identificación de productos forestales no maderables tropicales con potencial para la extracción sostenible y rentable en un sistema bajo manejo. Estudiamos el efecto demográfico y los beneficios económicos de la cosecha de la madera aromática gabaru de árboles de Aquilaria malaccenis Lam infectados por bongos en el Parque Nacional Gunung Palung Indonesia para evaluar el potencial de manejo de la madera. Arboles de Aquilaria malaccenis $>20 \mathrm{~cm}$ de diámetro ocurrieron en bajas densidades precosecha $\left(0.16-0.32 \mathrm{ha}^{-1}\right)$ pero se distribuyeron en cinco de los seis tipos de bosque muestreados. Durante una cosecha reciente, $75 \%$ de los árboles fueron cortados, con intensidades de cosecha entre 50 y 100\% en los tipos de bosque. En conjunto, 50\% de los árboles contenían madera gabaru, pero árboles de elevaciones mayores contenían madera gabaru más frecuentemente (73\%) que árboles de el-

Paper submitted December 11, 1998; revised manuscript accepted February 5, 2001. 
evaciones menores (27\%). La densidad promedio de regeneración (juveniles $>15 \mathrm{~cm}$ de altura) cerca de árboles adultos (de 3 a $7 \mathrm{~m}$ de distancia) fue de $0.2 \mathrm{~m}^{-2}$, 200 veces mayor que en el bosque (10 ba ${ }^{-1}$ ), pero se requieren datos a largo plazo sobre el crecimiento y la supervivencia para determinar si la regeneración es suficiente para la recuperación de la población. La extracción de madera gabaru de Gunung Palung fue muy redituable, generando un rendimiento financiero bruto estimado en US $\$ 8.80$ diarios, el triple del salario promedio en la zona. Sin embargo, la cosecha sostenible estimada de madera gabaru en densidades naturales de árboles genera un valor presente neto de sólo $\$ 10.83 \mathrm{ha}^{-1}$, mucho menor que el de la cosecha comercial de madera, uso dominante del bosque en Kalimantan. Sin embargo, los rendimientos por unidad de área podrían mejorar sustancialmente mediante la instrumentación de métodos silviculturales para incrementar la densidad de árboles, incrementar la proporción de árboles que producen madera gabaru y reducir el intervalo de tiempo entre cosechas sucesivas. El potencial económico de la madera gabaru es poco usual entre los productos forestales no maderables y justifica la experimentación para desarrollar métodos de cultivo en pequeña escala.

\section{Introduction}

Mechanized logging of lowland tropical rainforest is one of the most profitable, short-term uses of tropical forests, but it is also one of the most destructive. Historically, these facts have fostered a view that generating profit and conserving biodiversity are incompatible in tropical forests (Barber et al. 1994). More recently, however, it has been argued that establishing extractive reserves for the sustainable harvest of marketable nontimber forest products (NTFP) has the potential to unite economic and conservation goals by promoting nature conservation (Gradwohl \& Greenburg 1988; Plotkin \& Famolare 1992) while maximizing long-term economic returns per unit area (Fearnside 1989; Schwartzman 1989; Panayotou \& Ashton 1992).

Critics of the extractive reserve concept dispute claims that harvesting tropical NTFP has little negative effect on forest (Browder 1992; Hall \& Bawa 1993) and generates superior financial profits (Putz 1992; Salafsky et al. 1993). In principle, some NTFP plants may be harvested with modest effect on the exploited population (Peters 1990), but in practice many NTFP are overharvested (Whitkowski et al. 1994; Murali et al. 1996; O'Brien \& Kinnaird 1996), affecting both the target population and animals that utilize the harvested product (Bodmer et al. 1990; Kinnaird 1992). Furthermore, years after well-publicized valuations of NTFP extraction in Latin America (Peters et al. 1989; Balick \& Mendelsohn 1992), it appears that NTFP harvesting in unmanaged forest rarely generates more long-term financial profits than do alternative forest uses (Godoy et al. 1993; Grimes et al. 1994; Hedge et al. 1996).

Current overharvesting and low profitability of NTFP in unmanaged forest is not proof that sustainable and profitable extraction in a managed system is impossible. Combining economic and ecological data provides a powerful tool for identifying key parameters that could be manipulated in a managed system to improve the profitability and sustainability of extraction (Schulze et al. 1994). Yet, quantitative studies on the population ecology of NTFP species and the effect of harvesting them are rare (but see Fong 1992; Whitkowski et al. 1994; O'Brien \& Kinnaird 1996; Shankar et al. 1996), and this lack of technical information to inform management systems has undoubtedly limited the interest of government planners and investors in NTFP development.

We assessed the management potential of the NTFP gaharu wood, harvested from diseased trees of Aquilaria malaccensis Lam. (Thymeleaceae) in unmanaged rainforest of West Kalimantan, Indonesia. We studied the population ecology of $A$. malaccensis, the effect of harvesting on the tree population, and the net financial returns generated by gaharu-wood extraction. We addressed the following questions: (1) What were the habitat distribution, density, and size structure of $A$. malaccensis trees before and after exploitation? (2) What percentage of trees contained gaharu wood and how did this vary by forest type and tree size? (3) What was the net financial return per day earned by gaharu-wood collectors? (4) What is the net present value per hectare of gaharu wood in natural forest?

\section{Gaharu Wood Product}

Gaharu wood is the aromatic, resin-impregnated heartwood harvested throughout south Asia from five species of trees in the genus Aquilaria (Hou 1960, 1964). Unlike other resin products, gaharu is not tapped, but accumulates inside the tree and impregnates wood tissue to form aromatic nodules called gaharu wood. Gaharu wood is produced only by trees infected with a fungal pathogen that induces resin formation (Bose 1938; Bhattacharya et al. 1952). The epidemiology of the disease is not understood, but wood-boring insects (Skeats 1901; Jalaluddin 1977) and ants (Peluso 1983) have been implicated as vectors of the fungal pathogen(s). Reports of the proportion of Aquilaria trees in natural forest that contain gaharu-wood range from almost zero (Skeats 1901; Gimlette 1939) to $10 \%$ (Gianno 1990). Gaharu wood is harvested by 
felling trees that appear diseased and cutting away uninfected wood to remove the resin nodules. Experienced collectors assess the disease status of a tree by examining characteristics of the bark, sapwood, branch scars, and tree crown before felling.

Gaharu wood has a trade history in Asia that spans millennia (Burkill 1935; Wheatley 1959). Today, it is among the most valuable forest products harvested in Southeast Asia (Nurhayanti 1988; Anonymous 1994). In the villages we studied, high-quality gaharu wood sold for up to US $\$ 500 / \mathrm{kg}$, with typical prices ranging from $\$ 60$ to $\$ 80 / \mathrm{kg}$ (G. Paoli, unpublished data). Gaharu wood is harvested intensively throughout Indonesia by private collectors and exported as a raw material to Asian and Arab markets (Nurhayanti 1988), where high-quality wood becomes incense and low-quality wood is processed to extract oil used in religious ceremonies, cosmetics, and perfume (Anonymous 1994).

Due to the high value of gaharu wood, Aquilaria has been severely overharvested throughout Asia during the last 20 years (Peluso 1983). In 1994 the species was placed on Appendix II of the Convention on the International Trade in Endangered Species (CITES) (MacBryde 1994). Listing on CITES Appendix I prohibits international trade in gaharu wood.

\section{Study Site and Species}

We collected data on $A$. malaccensis at the Cabang Panti Research Station in Gunung Palung National Park, West Kalimantan, Indonesia, from September 1991 through November 1992. Gunung Palung National Park (hereafter Gunung Palung) is a 100,000-ha rainforest preserve with a diverse mosaic of tropical rainforest types. Cabang Panti Research Station (hereafter Cabang Panti) is a 1500-ha long-term research area occupying the major river valley of the western slope of Mt. Palung. Annual rainfall at Cabang Panti is $4275 \pm 484 \mathrm{~mm}$, with periods of reduced rainfall from January to February and June to September. We sampled the following six forest types along an elevational gradient (approximate area of each type within the park in parentheses): peat swamp $(29,800$ ha) and freshwater swamp forest (19,800 ha) near sea level; alluvial bench forest along the Air Putih River (10,000 ha); lowland mixed dipterocarp forest on sandstone- and quartzite-derived soils $<100 \mathrm{~m}$ above sea level (lowland sandstone forest; 14,000 ha); lowland mixed dipterocarp forest on granite-derived soils $<360 \mathrm{~m}$ above sea level (lowland granite forest; 16,900 ha); and lower montane forest on granite slopes 360-750 $\mathrm{m}$ above sea level ( $5700 \mathrm{ha})$. These forest types compose $>97 \%$ of the total park area.

Harvesting of gaharu wood has occurred in forests surrounding Gunung Palung for centuries. According to village elders, however, Aquilaria trees were harvested al- most exclusively near villages, where the tree was once abundant, until the species was discovered in the park in 1988. Harvesting forest products from the park is illegal, but the discovery of gaharu wood initiated two waves of exploitation. The first, from May 1988 to March 1989, removed most of the gaharu wood from Gunung Palung, except at Cabang Panti, where the presence of researchers reduced harvest activity. Harvesting during the second wave, August to September 1991, when local prices increased and researchers were absent, removed most of the remaining trees from Cabang Panti. We use "preharvest" to refer to the time before the first wave and "postharvest" to refer to the time after the second wave.

Three species of Aquilaria occur in Kalimantan, but A. malaccensis is far more common than either A. $m i$ crocarpa or A. beccariana (Hou 1960; Whitmore 1973). Fertile collections of four Aquilaria trees at Cabang Panti were examined and positively identified as $A$. malaccensis by G.D.P. using type specimens (Arnold Arboretum, Harvard University, Cambridge, Massachusetts). A. microcarpa and $A$. beccariana have not been recorded at the site. At Cabang Panti, A. malaccensis is a mid- to upperstory canopy tree producing a dehiscent capsular fruit $(1 \times 1 \times 0.5 \mathrm{~cm})$ that contains one to two thinly arillate brown seeds $(0.4 \times 0.4 \times 0.5 \mathrm{~cm})$ suspended $1-2 \mathrm{~cm}$ from the husk at maturity, suggesting that seeds are dispersed by birds (Gautier-Hion et al. 1985). Seeds germinate within 30 days (Beniwal 1989).

\section{Methods}

\section{Ecological Assessment}

We estimated the distribution, density, and size structure of $A$. malaccensis trees in a survey of all six forest types. In alluvial bench, lowland sandstone, lowland granite, and lower montane forest, we established 25 plots (each 1 ha, $20 \times 500 \mathrm{~m}$ ) beginning at randomly chosen points along permanent trails and oriented away from trails at randomly chosen angles. In peat swamp forest, we surveyed 50 plots (each $0.5 \mathrm{ha}, 20 \times 250 \mathrm{~m}$ ) placed similarly. Although the 125 ha of plots originated from permanent trails, the plots were sufficiently long to traverse several ridge and valley subsystems within the watershed, making a serious spatial bias unlikely. We tested for the occurrence of $A$. malaccensis in freshwater swamp forest by surveying 2.4 ha of randomly placed permanent vegetation plots established in 1985 for phenological studies: 10 plots of 0.1 ha $(20 \times 50 \mathrm{~m})$ and another 7 plots of 0.2 ha $(20 \times 100 \mathrm{~m})$. Because only 2.4 ha were sampled in freshwater swamp, we did not estimate densities there. All 127.4 ha of fixed-area plots were surveyed for felled and standing $A$. malaccensis trees of $\geq 20 \mathrm{~cm}$ in diameter at breast height (dbh; hereafter called Aquilaria trees). 
This minimum size was chosen because felled Aquilaria trees at Cabang Panti were rarely $<20 \mathrm{~cm} d b h$, and collectors reported that such trees seldom contain sufficient gaharu wood to justify harvesting them. In addition to the 127.4 ha of fixed-area plots, felled and standing $A q$ uilaria trees were sampled opportunistically along permanent trails within each forest type. These opportunistic samples were not used to estimate population densities or the percentage of trees harvested, but they increased sample sizes for comparisons of tree size (dbh) among forest types and the proportion of trees that contained gaharu wood.

We examined Aquilaria trees harvested in 1991 with experienced gaharu-wood collectors to define the best criteria for assessing the disease status of trees we encountered during the surveys. Trees were first classified as felled or standing. Felled trees were then categorized as follows:

(1) contained gaharu wood, bole deeply cut into along $>50 \%$ of its length and small, similar-sized wood fragments indicated that uninfected wood was cut away to remove gaharu wood;

(2) contained no gaharu wood, bole cut into at intervals and to various depths along $<50 \%$ of its length and large, multisized wood fragments suggest that uninfected wood was not cut away to remove gaharu wood; or

(3) ambiguous, could not be classified as (1) or (2), but axe marks indicate that the tree had been felled and examined for gaharu wood.

Standing trees were placed into categories (4) or (5) to indicate whether they had been found by collectors:

(4) found, but contained no gaharu wood, and bark stripped from the bole and/or axe marks indicate that the tree was examined by a collector to assess disease status; or

(5) not found, no visible signs of a collector having examined the tree.

The density and size of gaps created by felling Aquilaria trees was estimated during the survey of 1-ha plots. Gap density was defined as the density of felled trees. Gap size was estimated for 10 randomly chosen felled trees by producing a scale drawing from which area in square meters was estimated.

Throughout the four nonswamp forest types (alluvial bench, lowland sandstone, lowland granite, and lower montane), we looked for regeneration near Aquilaria trees to infer the reproductive size threshold of Aquilaria and to quantify the overall density and size structure of regeneration near parents. Twenty-two trees were randomly chosen from a list of 53 felled $(n=13)$ and standing $(n=9)$ Aquilaria trees $(18-83 \mathrm{~cm} \mathrm{dbh})$, with the restriction that chosen trees must be $>50 \mathrm{~m}$ apart. For the first 10 trees surveyed, Aquilaria individu- als $>15 \mathrm{~cm}$ in height were mapped in circular plots of $50-\mathrm{m}$ radius ( 0.79 ha) centered on the tree bole or stump. Because $98 \%$ of regeneration occurred within 30 $\mathrm{m}$, the remaining 12 trees were surveyed in circular plots of 30-m radius ( $0.28 \mathrm{ha}$ ). In all 22 plots (total area $6.16 \mathrm{ha}$ ), all Aquilaria individuals were tagged and measured for height and dbh of $\geq 1 \mathrm{~cm}$.

In lowland sandstone forest, we examined the density and size structure of regeneration more extensively to quantify regeneration found at random in the forest and to compare regeneration "near" Aquilaria trees $(<20 \mathrm{~m}$ away) with regeneration "away" from trees $(\geq 20 \mathrm{~m}$ away). The motivation for comparing regeneration near and away from parents was to test for evidence that recruitment may be enhanced by dispersal far from the parent (Clark \& Clark 1984). Such evidence might suggest management interventions, such as transplanting naturally occurring seedlings away from parents, to promote population recovery. We chose lowland sandstone forest because it is among the most widespread forest types in the park and tree densities were relatively high in lowland sandstone prior to harvest.

We quantified regeneration near parents in lowland sandstone by pooling data from the seven trees in this habitat that were sampled during the original 22-tree survey of regeneration within $30 \mathrm{~m}$ of trees. We recorded the number of juvenile Aquilaria in successive 1-m-wide annuli at increasing distance from the adult tree. Ninetyeight percent of regeneration $<30 \mathrm{~m}$ from trees occurred within $20 \mathrm{~m}$, so a distance of $<20 \mathrm{~m}$ from parents was chosen to represent the density of regeneration near trees.

We sampled regeneration at random in lowland sandstone forest on 50 plots (each $0.2 \mathrm{ha}, 20 \times 100 \mathrm{~m}$; total area $10 \mathrm{ha}$ ) positioned at randomly chosen points along trails and oriented from trails at randomly chosen angles. Each plot was surveyed for regeneration of $\geq 15 \mathrm{~cm}$ in height, and individuals were tagged and measured for height and $\mathrm{dbh}$ of $>1 \mathrm{~cm}$. Canopy cover above each individual was classified as open, partially closed, or closed.

We then used these same 0.2 -ha plots to quantify regeneration away (at least $20 \mathrm{~m}$ ) from parent trees. To determine which areas satisfied this criterion, we surveyed a 20-m-wide band surrounding each plot and recorded whether felled or standing Aquilaria trees occurred within $20 \mathrm{~m}$ of the plot. Plots containing Aquilaria trees or with trees within $20 \mathrm{~m}$ of their edges were disqualified from the sample of trees $\geq 20 \mathrm{~m}$ away from parents ( $n=8$ plots) and replaced with plots randomly positioned $\geq 20 \mathrm{~m}$ from Aquilaria trees, thus restoring a 10-ha sample area.

\section{Economic Assessment}

Economic data on gaharu wood were obtained through interviews of five gaharu wood collectors from Rantau Panjang village on the west-northwest border of Gunung 
Palung. Collectors from Rantau Panjang have harvested gaharu wood since 1982, the onset of commercial harvesting in the Gunung Palung region. Each of the interviewees had harvested gaharu wood from Cabang Panti on at least two, and usually several, occasions. Collectors varied in age (24-33), years of harvesting experience (4-9), and number of collecting trips (12-90).

Each collector was interviewed independently by G.D.P., who had been living in the area continuously for 15 months and conversing daily with villagers in the Indonesian language (Bahasa Indonesia). Information was gathered to answer the following questions:

(1) What was the lowest, highest, and typical gross financial value of gaharu wood collected during one trip?

(2) What were the total capital and labor costs of a typical collection trip?

(3) What was the lowest, highest, and typical gross financial value of gaharu wood harvested from a single diseased tree?

We used the economic data to compute three financial parameters of gaharu-wood extraction. The daily net financial return (NFR) on extraction was computed to compare the income earned by gaharu-wood extraction with that of village employment:

$$
\mathrm{NFR}=\frac{\text { gross returns per trip } / \text { trip duration }}{\text { daily labor cost }+ \text { daily capital cost }},
$$

where gross returns per trip is the estimated gross financial value of gaharu wood collected during a typical trip, trip duration is the average trip length (days), daily labor cost is the estimated daily village wage, and daily capital cost is the estimated total value of cash expenditures during a trip, divided by trip duration.

The net financial value $\left(\mathrm{NFV}_{T}\right)$ of gaharu wood per diseased tree was estimated from interviews by computing the mean gross financial value of gaharu wood in a typical diseased tree and then subtracting the estimated cost of capital and labor to harvest one tree. The estimated cost of harvesting one tree was computed as the sum of capital and labor costs per day to harvest gaharu wood, multiplied by the average number of days necessary to harvest gaharu wood equal in value to the gross financial value of a typical tree. The average number of days necessary to harvest one tree was estimated as the gross financial value per diseased tree, divided by the gross financial returns per trip, times the average trip duration (14 days).

Finally, we computed the net present value (NPV) of gaharu wood per hectare (Dixon \& Hufschmidt 1985) as $\mathrm{NPV}=\mathrm{NFV}_{H} /\left(1-e^{-r t}\right)$, where $\mathrm{NFV}_{H}$ is the net financial value of gaharu wood per hectare; $r$ is the annual discount rate; and $t$ is the number of years between harvests. When $t=1$, the flow of revenues is treated as an annuity. When $t>1$, revenues accrue at frequencies of
$>1$ year. The parameter $r$ discounts the current value of net revenues that accrue in the future. We used a discount rate of $10 \%$. The longer the time interval between successive harvests $(t)$ and the larger the amount by which future revenues are discounted each year $(r)$, the less future harvests are valued today. Data from which to calculate a sustainable rotation period are not available. We assumed a sustained-yield harvest of gaharu wood every 35 years, the midpoint of estimates that low-quality gaharu wood can be harvested from 20-year-old trees and high-quality gaharu wood from 50-year-old trees (Gimlette 1939; Beniwal 1989; Mahindru 1992). We report financial values throughout the paper in U.S. dollars calculated from a composite 1988-1989 exchange rate of 1700 Rupiah per U.S. dollars.

\section{Results}

\section{Ecological Assessment}

\section{TREE POPULATION BEFORE AND AFTER HARVEST}

Before harvesting began, Aquilaria malaccensis trees had a wide habitat distribution at Cabang Panti, occurring in five of the six forest types sampled: freshwater swamp, alluvial bench, lowland sandstone, lowland granite, and lower montane (Table 1). Tree densities were low, however, in all forest types where densities were estimated, ranging from $0.16 \pm 0.07 / \mathrm{ha}$ in alluvial bench and lower montane to $0.32 \pm 0.1 / \mathrm{ha}$ in lowland sandstone and lowland granite forests (Table 1). One Aquilaria tree was found in the 2.4 ha surveyed in freshwater swamp forest, and no trees were found in the 25 ha surveyed in peat swamp forest.

The size structure of the Aquilaria tree population before harvest was dominated by trees $<40 \mathrm{~cm}$ dbh (Fig. 1). The mean dbh of Aquilaria trees did not differ significantly among formations based either on the randomplot sample (Kruskal-Wallis test; $n=24, H=3.955, p=$ $0.412)$ or the combined random-plot and trail-side samples (Kruskal-Wallis test; $n=46, H=0.7363, p=0.946$ ).

Trees were felled in every formation where Aquilaria trees occurred (Table 1). Overall, collectors felled $75 \%$ (18 of 24) of trees in the 125-ha sample of random plots. The intensity of harvesting ranged from 50\% (alluvial bench) to $100 \%$ (lower montane), leaving a density of trees that ranged from 0 (lower montane) to $0.12 \pm$ $0.03 /$ ha (lowland sandstone; Table 1 ). Across forest types, the density of gaps created by felling was low, ranging from $0.08 \pm 0.06 /$ ha (alluvial bench) to $0.28 \pm 0.09 /$ ha (lowland granite), and the mean gap size was $225 \pm 85$ $\mathrm{m}^{2}$ ( $n=10$ trees), ranging from 92 to $345 \mathrm{~m}^{2}$.

Trees were felled in all size classes (Fig. 1). In the random-plot sample, the frequency of trees $<40 \mathrm{~cm}$ dbh before harvest (12 of 24 trees) equaled that of trees after 
Table 1. Density (mean $\pm 1 \mathrm{SE}$ ) of Aquilaria malaccensis trees $\geq 20 \mathrm{~cm}$ dbh, their harvest status, and the abundance of regeneration near adults in five major forest types at Gunung Palung National Park, West Kalimantan, Indonesia.

\begin{tabular}{|c|c|c|c|c|c|}
\hline Parameter & peat swamp & alluvial bench & lowland sandstone & lowland granite & lower montane \\
\hline preharvest density & 0 & $0.16 \pm 0.07$ & $0.32 \pm 0.1$ & $0.32 \pm 0.1$ & $0.16 \pm 0.07$ \\
\hline postharvest density & 0 & $0.08 \pm 0.03$ & $0.12 \pm 0.03$ & $0.04 \pm 0.02$ & 0 \\
\hline \multicolumn{6}{|l|}{ Harvest status } \\
\hline felled, ambiguous & 0 & 0 & 0 & 3 & 0 \\
\hline not felled & 0 & 2 & 3 & 1 & 0 \\
\hline \multicolumn{6}{|l|}{ Regeneration near adults } \\
\hline total juveniles & $\mathrm{nd}^{*}$ & $4.5 \pm 3.0$ & $30.8 \pm 11.4$ & $40.3 \pm 12.6$ & $1.8 \pm 1.0$ \\
\hline adults sampled & & $(n=3)$ & $(n=7)$ & $(n=10)$ & $(n=2)$ \\
\hline
\end{tabular}

*No data (nd) were collected because no parent trees were found.

harvest ( 3 of 6 trees), and the mean dbh of trees before harvest ( $44 \pm 3 \mathrm{~cm}, n=24$ ) did not differ from that of residual trees after harvest $(45 \pm 8 \mathrm{~cm}, n=6$; MannWhitney test, $U=68.5, p=0.856)$.

\section{FREQUENCY OF GAHARU WOOD FORMATION}

Trees of each harvesting category (Table 1) were found during the 125-ha survey of random plots. Of the 18 trees felled, 11 contained gaharu wood, 4 did not, and 3 were ambiguous. Of the 6 standing trees, 4 were examined by collectors but not felled, whereas $2(8 \%$ of the total) were not discovered by collectors. Overall, $50 \%$ of Aquilaria trees contained gaharu wood. This was estimated from the random-plot sample by computing the ratio of trees that contained gaharu wood (11) to the total number of trees found by collectors (22; Table 1 ). The frequency of infection among forest types varied,

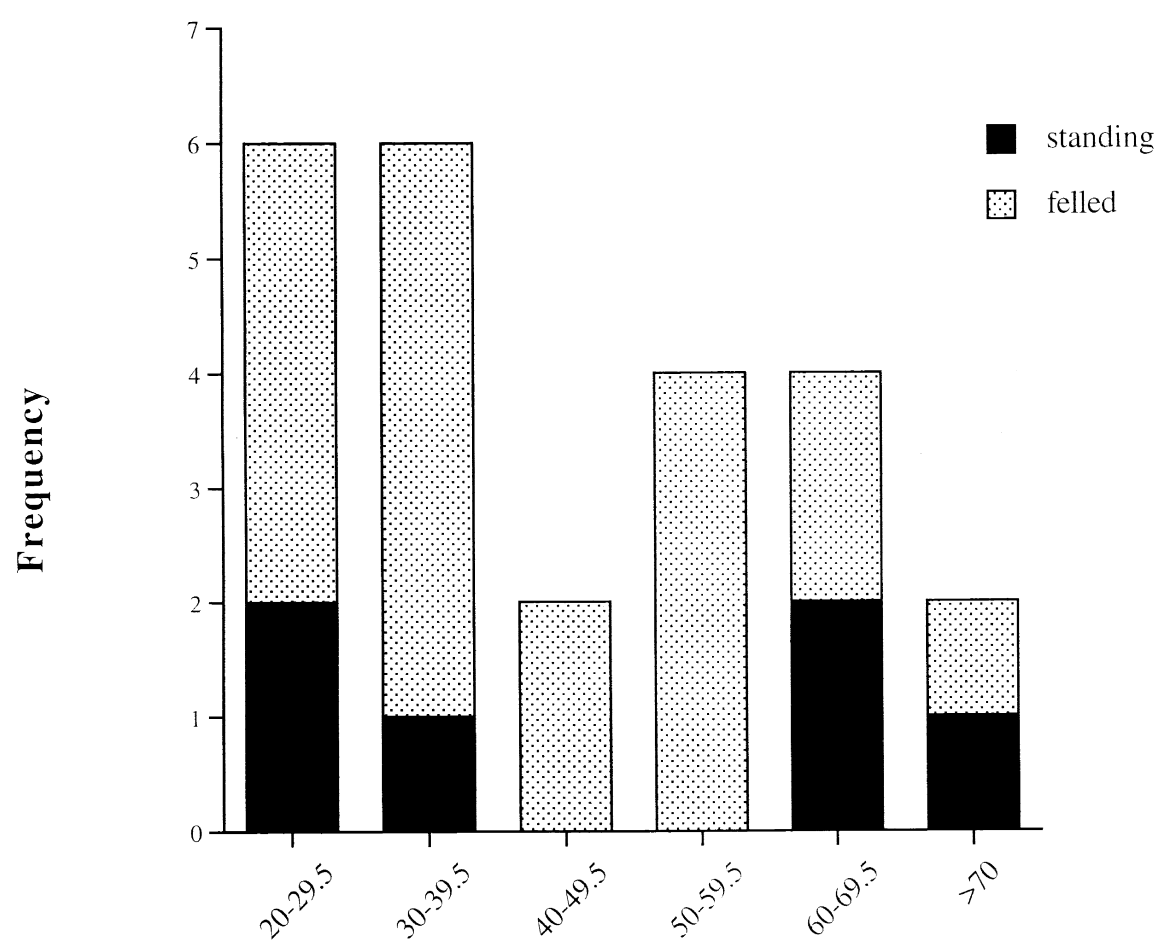

DBH $(\mathrm{cm})$
Figure 1. Size distribution of Aquilaria malaccensis trees of $\geq 20 \mathrm{~cm}$ diameter at breast beight (DBH) in five rain forest types before harvest (black plus speckled bars) and after barvest (black bars only), from 125 plots, each $20 \times$ $500 \mathrm{~m}$ (total area $125 \mathrm{ba}$ ). 
ranging from $25 \%$ ( 2 of 8 ) in lowland sandstone forest to $100 \%$ ( 4 of 4 ) in upper montane forest. The mean dbh of trees that contained gaharu wood did not differ from that of trees that did not contain gaharu wood, based on either the random-plot sample (39 \pm 5 vs. $51 \pm 5 \mathrm{~cm}$; Mann-Whitney test, $n=20, U=28, p=0.102$ ) or the combined plot and trail-side sample ( $43 \pm 4$ vs. $47 \pm 3$ cm; Mann-Whitney test, $n=38, U=145.5, p=0.306$ ).

Soil nutrient availability in soils derived from granite at Cabang Panti is much lower than in soils derived from sedimentary rock and alluvium (G. Paoli, unpublished data). Thus, we classified forest on granite soils as upper-elevation forest (where soils are less fertile) and alluvial bench and lowland sandstone forest as lower-elevation forests (where soils are more fertile) and compared the frequency of gaharu wood formation between these groups using the combined random-plot and trail-side samples. Trees at upper elevations were significantly more likely to contain gaharu wood $(73 \%, 16$ of 22$)$ than trees at lower elevations $(27 \%, 4$ of 15 ; chi-square test, $\chi^{2}=4.27, p=0.041$ ).

\section{PATTERNS OF REGENERATION}

Among trees $<35 \mathrm{~cm} \mathrm{dbh}$, only 2 of 8 had any conspecific regeneration within $30 \mathrm{~m}$. In contrast, for trees $\geq 35 \mathrm{~cm} \mathrm{dbh}, 12$ of 14 had at least some regeneration within $30 \mathrm{~m}$, and most were surrounded by many conspecific juveniles. We concluded that Aquilaria trees at Cabang Panti reach reproductive maturity at approximately $35 \mathrm{~cm} \mathrm{dbh}$. Among trees $\geq 35 \mathrm{~cm} \mathrm{dbh}$, however, the size of parents was unrelated to the abundance of regeneration surrounding them. The abundance of regeneration surrounding parents displayed the same pattern among forest types as the abundance of Aquilaria trees: regeneration was more abundant in lowland sandstone and granite forest than in alluvial bench and lower montane forest (Table 1). When data were pooled across all forest types, the mean density of regeneration within 3-7 $\mathrm{m}$ of Aquilaria trees exceeded $2 / \mathrm{m}^{2}$ and dropped sharply to $<0.01 / \mathrm{m}^{2}$ beyond $15 \mathrm{~m}$.

In lowland sandstone forest, where regeneration was sampled most extensively, the density of postharvest regeneration at random in the forest was 2.02 per 0.2 -ha plot, or approximately 10/ha, 200 times lower than the mean density of regeneration within 3-7 m of parent trees in the same forest type. The size structure of regeneration sampled at random in lowland sandstone forest was highly skewed and dominated by individuals $<200$ $\mathrm{cm}$ in height (Fig. 2). Densities of individuals $>6 \mathrm{~m}$ in height were extremely low $(0.6 / \mathrm{ha})$, but a few individuals in the pole and subadult tree size classes were found in the 10 ha surveyed.

The size structure of Aquilaria regeneration within $20 \mathrm{~m}$ of parent trees in lowland sandstone forest differed from that of regeneration more than $20 \mathrm{~m}$ from trees (Fig. 3). Seedlings and saplings were significantly smaller near adult trees $(125 \pm 9 \mathrm{~cm}, n=162)$ than away from adult trees $(183 \pm 20 \mathrm{~cm}, n=92$; MannWhitney test, $U=5715, p=0.002$ ), and the relative frequency of individuals of $>100 \mathrm{~cm}$ in height was significantly lower near trees (68 of 162) than away from trees ( 55 of 92; chi-square test, $\chi^{2}=3.842, p=0.049$ ).

\section{Economic Assessment}

The mean estimated gross financial return reported from a typical 14-day collection trip was $\$ 124$, or $\$ 8.80$

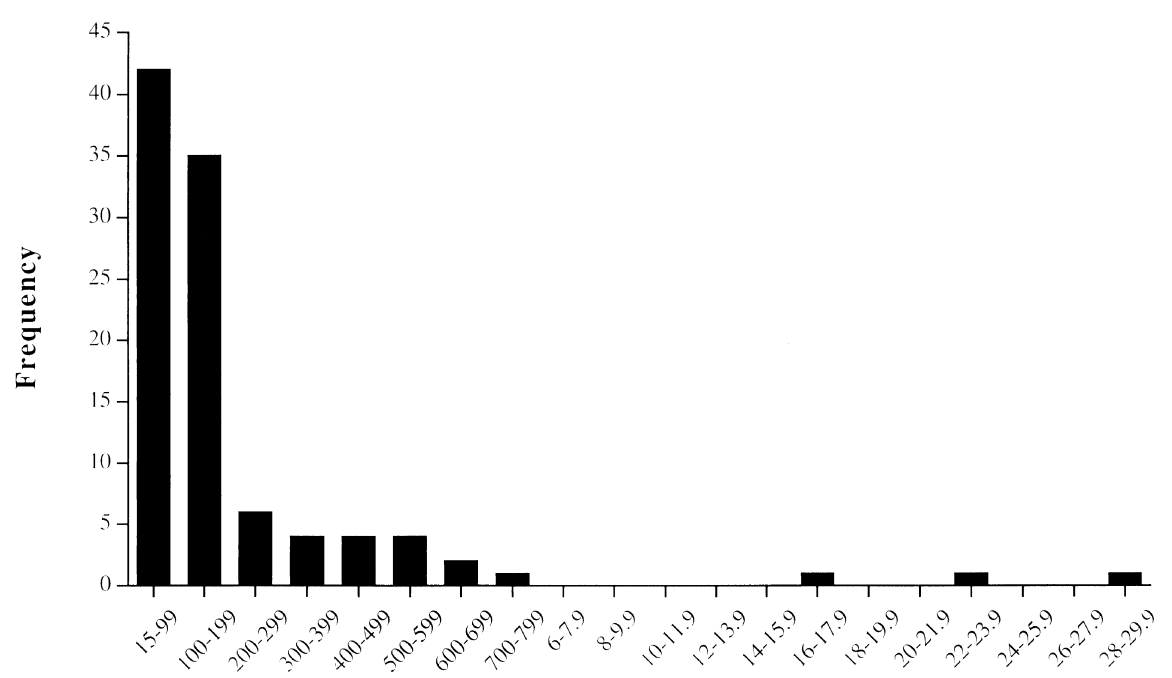

Height $(\mathrm{cm})$
DBH $(\mathbf{c m})$
Figure 2. Post-harvest size distribution of the Aquilaria malaccensis population ( $\mathrm{n}=102$ individuals $\geq 15 \mathrm{~cm}$ beight) sampled at random in lowland sandstone forest (50 plots, each $20 \times 50 \mathrm{~m}$; total area $10 \mathrm{ha}$ ). Size classes for individuals of $\geq 6.0 \mathrm{~cm}$ dbh are defined by diameter at breast height. 


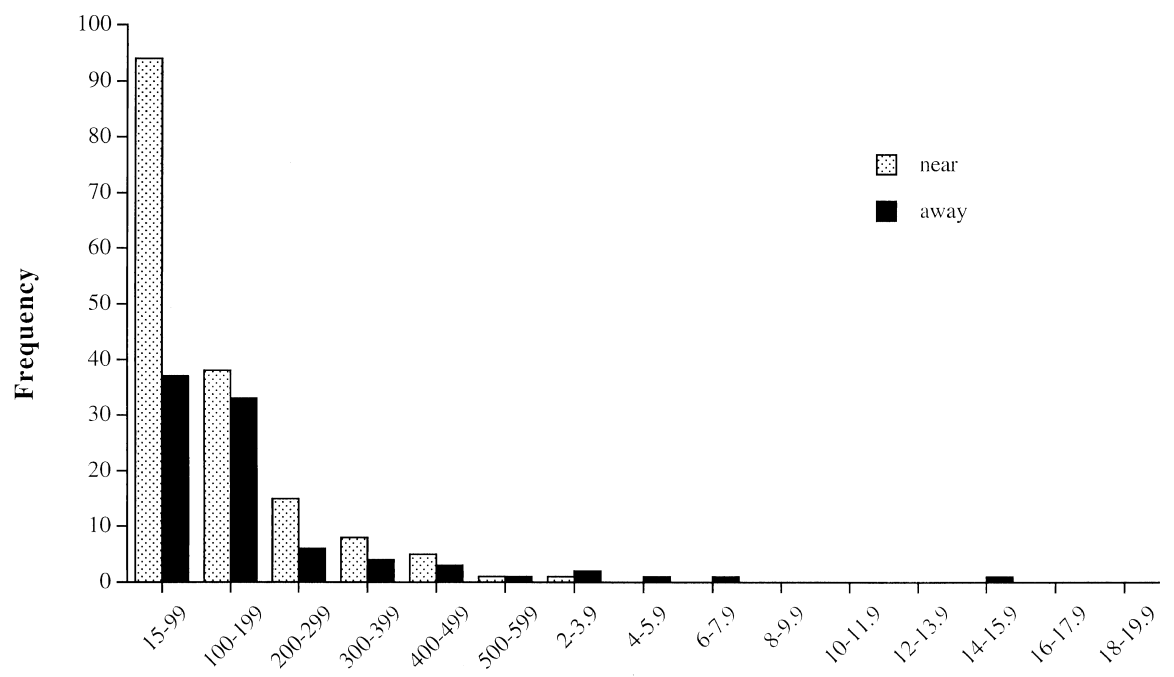

Height $(\mathbf{c m})$

DBH $(\mathrm{cm})$
Figure 3. Postharvest size distribution of Aquilaria malaccensis regeneration ( $\geq 15 \mathrm{~cm}$ height) near parents $(<20 \mathrm{~m}$ from tree; 9 plots, each 20-m-radius circle around parent tree; total area $1.13 \mathrm{ha}$ ) and away from parents $(\geq 20 \mathrm{~m}$ from tree; 50 plots, each $20 \times 50 \mathrm{~m}$; total area $10 \mathrm{ba}$ ) in lowland sandstone forest. per day (Table 2). Minimum gross returns were zero for all respondents, and maximum gross returns ranged from $\$ 167$ to $\$ 3570$.

The mean estimated capital cost per day of a typical trip was $\$ 0.90$ (Table 3). These costs were usually met by local gaharu-wood buyers, who loaned money to collectors in exchange for a promise to sell gaharu wood to the buyer. The mean estimated net financial return per day was $\$ 5.25$ (Table 2 ). This was calculated by subtracting the sum of mean capital costs per day (\$0.90) and daily village wage $(\$ 2.65)$ from the mean gross financial returns per day (\$8.80). Gaharu-wood extraction was therefore extremely profitable, especially considering that net return was calculated as the daily profit above the daily village wage, which is not always available.

The mean estimated gross financial value of gaharu wood in a typical diseased tree was \$129 (Table 2). Among collectors, the minimum estimated gross financial value per tree ranged from $\$ 6$ to $\$ 9$, and the maximum ranged from $\$ 529$ to $\$ 7650$. The mean estimated cost of capital (\$14) and labor (\$40) to harvest a single tree was \$54
(Table 2). Thus, subtracting the estimated cost of harvesting a tree (\$54) from the estimated gross financial value of a tree (\$129) yielded an estimated net financial value per tree of $\$ 75$ (Table 2).

The mean estimated density of diseased trees in forest types where Aquilaria occurred was 0.14 trees/ha and ranged from 0.04 (alluvial bench) to 0.24 /ha (lowland granite; Table 3 ). The mean estimated net financial value of diseased trees in these same forest types was $\$ 10.50$ / ha and ranged from $\$ 3$ (alluvial bench) to $\$ 18$ (lowland granite forest). Based on our observation that $92 \%$ of $A q$ uilaria trees in the 125-ha survey of random plots were found by collectors (Table 1), we estimate that $92 \%$ of the gaharu wood available at Cabang Panti was actually harvested.

Assuming a sustainable harvest every thirty-five years and a discount rate of $10 \%$, the mean estimated net present value per hectare of gaharu wood available for harvest in forest types where Aquilaria occurred was \$10.83, ranging from $\$ 3.44$ (alluvial bench) to $\$ 18.56$ (lowland granite; Table 3).

Table 2. Estimated net financial return (\$US) per day earned by gaharu-wood collectors and the net financial value per diseased $A q u$ ilaria malaccensis tree at Gunung Palung National Park, West Kalimantan, Indonesia.

\begin{tabular}{lccccccccc} 
Gross return & $\begin{array}{c}\text { Gross } \\
\text { per trip } \\
\text { (range) }\end{array}$ & $\begin{array}{c}\text { Capital } \\
\text { return } \\
\text { per day }\end{array}$ & $\begin{array}{c}\text { costs } \\
\text { per day }\end{array}$ & $\begin{array}{c}\text { Labor cost } \\
\text { per day }\end{array}$ & $\begin{array}{c}\text { Net return } \\
\text { per day }\end{array}$ & $\begin{array}{c}\text { Gross value } \\
\text { per tree } \\
\text { (range) }\end{array}$ & $\begin{array}{c}\text { Total cost } \\
\text { per day }\end{array}$ & $\begin{array}{c}\text { Total cost } \\
\text { per tree }\end{array}$ & $\begin{array}{c}\text { Net value } \\
\text { per tree }\end{array}$ \\
\hline 1 & $94(0-167)$ & 6.70 & 0.65 & 2.35 & 3.70 & $161(9-529)$ & 3.00 & 72 & 89 \\
2 & $97(0-414)$ & 6.90 & 0.65 & 2.65 & 3.60 & $118(6-824)$ & 3.30 & 56 & 62 \\
3 & $191(0-3570)$ & 13.60 & 1.25 & 2.95 & 9.40 & $132(7-7650)$ & 4.20 & 41 & 91 \\
4 & $114(0-515)$ & 8.10 & 1.05 & 2.65 & 4.40 & $104(9-529)$ & 3.70 & 47 & 57 \\
Mean & 124 & 8.80 & 0.90 & 2.65 & 5.25 & 129 & 3.55 & 54 \\
\hline
\end{tabular}


Table 3. Estimated net present value per hectare of gaharu wood in five major forest types at Gunung Palung National Park,

West Kalimantan, Indonesia.

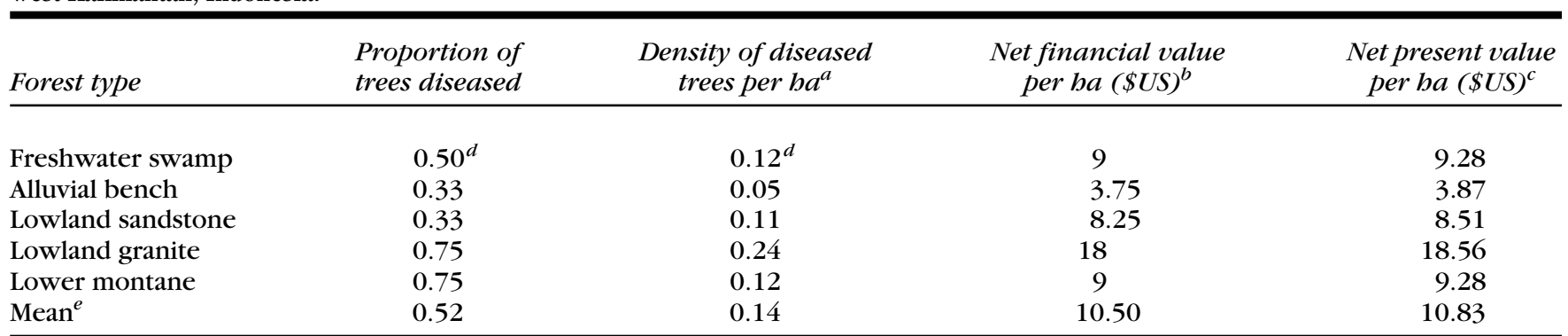

${ }^{a}$ Estimated tree density (Table 1) times the estimated proportion of trees that were diseased.

${ }^{b}$ Density of diseased trees times the mean estimated net financial value of a diseased tree (\$75; Table 2).

${ }^{c}$ Assuming a sustained-yield harvest every 35 years and a discount rate of $10 \%$.

${ }^{d}$ Overall mean was applied to freshwater swamp forest because of inadequate sampling in this forest type.

${ }^{e}$ Weighted by the proportion of total area in the study site represented by each forest type.

\section{Discussion}

\section{Ecological Assessment}

\section{ECOLOGY OF AQUILARIA}

The wide habitat distribution of Aquilaria at Cabang Panti suggests that its natural distribution in nonswamp forest is not strongly limited by environmental conditions that vary with elevation. Such a broad habitat distribution is uncommon among canopy tree species at Cabang Panti, yet it appears to be typical of Aquilaria in India (Beniwal 1989) and Peninsular Malaysia (LaFrankie 1994).

Although widespread, Aquilaria trees were rare throughout their range at Cabang Panti, reaching a maximum estimated density of $0.32 /$ ha before harvest. This is consistent with low densities reported in India (Beniwal 1989) and Peninsular Malaysia (LaFrankie 1994), but it contrasts with a report by Sidiyasa et al. (1986), who found stands of Aquilaria trees of $\geq 20 \mathrm{~cm}$ dbh in South Kalimantan, with densities of 100/ha on alluvial soils and 120/ha on sandstone-derived soils. Gaharu-wood collectors consider Aquilaria harvestable at only $20 \mathrm{~cm}$ dbh, far below the reproductive threshold, which we estimated at $35 \mathrm{~cm} \mathrm{dbh}$. Harvesting prior to maturity places the population at high risk of extinction unless "seed trees" are designated and spared from harvest.

Densities of regeneration near Aquilaria trees were highly variable among forest types but were highest in lowland sandstone and lowland granite forest, where adult densities were also highest (Table 1). This pattern suggests that differences in adult tree densities among forest types may be driven by differences in juvenile establishment and recruitment, but long-term demographic data are required to test this hypothesis. The size structure of Aquilaria regeneration was dominated by smaller size classes whether sampled at random in the forest (Fig. 2), near parents, or away from parents (Fig. 3). But the smaller average size and lower relative frequency of large recruits nearer parents than further away (Fig. 3) suggests that either (1) prior to sampling in 1991 (1-3 months after harvesting), natural conditions for regeneration were poorer near parents or (2) regeneration farther away is older, originating from parent trees that have since died and decomposed.

\section{FREQUENCY OF GAHARU WOOD INFECTION}

Our estimate that $50 \%$ of Aquilaria trees at Cabang Panti contained gaharu wood is much higher than anecdotal reports elsewhere, but it approximates collectors' estimates that one of three trees contained gaharu wood at Gunung Palung. That the frequency of gaharu-wood formation was unrelated to tree size confirms a report by Skeats (1901) that gaharu wood occurs in trees of any size greater than $25 \mathrm{~cm} \mathrm{dbh}$, but it contradicts reports by Bose (1938) and Jalaluddin (1977) that the frequency of gaharu-wood formation is higher in larger trees.

Collectors reported that Aquilaria trees growing under stressful conditions are more vulnerable to gaharuwood infection, based on their observations that the occurrence of gaharu wood is more frequent at high elevations and on poor soils. Although based on a sample of only 39 trees, our findings were consistent with these reports: trees at higher elevations on granite soils were more likely to contain gaharu wood than trees at lower elevations on sedimentary and alluvial soils. Confirmation of this pattern at other sites and explication of its cause(s) is of practical importance because the unpredictability of gaharu-wood formation in natural forest is considered the major impediment to cultivation in a managed system (Peluso 1983; Beniwal 1989; Gianno 1990; LaFrankie 1994).

\section{EFFECTS OF HARVESTING AND LIKELIHOOD OF POPULATION RECOVERY}

Overall, the intensive harvesting of gaharu wood at Gunung Palung appears to have caused only modest ecological disturbance. Felled trees were sparse $(0.08-0.28 / \mathrm{ha})$, 
and gaps thus created were small $\left(225 \pm 85 \mathrm{~m}^{2}\right)$. The percentage of tree biomass removed from the forest was low, and neither roads nor heavy equipment was used by collectors. Furthermore, the immediate reduction in availability of Aquilaria fruit caused by felling trees is unlikely to affect resident frugivores because Aquilaria appears to fruit supra-annually and in synchrony with a majority of canopy-tree species (M. Leighton, unpublished data), suggesting that Aquilaria is not a critical resource for resident frugivores during fruit-poor periods.

The effect of harvesting on Aquilaria, however, was severe. Most (75\%) of the stems of $\geq 20 \mathrm{~cm}$ dbh were removed from a population that already occurred at low densities (Table 1). This harvest intensity appears unsustainable, except perhaps with very long rotation periods. Population recovery may be most problematic in the lowland granite and lower montane forest types, where densities of trees were most affected, and regeneration in lower montane forest was also relatively scarce (Table 1). In these forest types, new seedling establishment will depend heavily on seed dispersal from parent trees in adjacent forest types until a local reproductive population is reestablished.

The effect of harvesting on Aquilaria trees could have been less severe without sacrificing the amount of gaharu wood harvested. In the 125-ha sample of random plots, 4 of 18 trees felled did not contain gaharu wood. Collectors reported that such trees were felled by novice collectors who felled trees indiscriminately, as reported elsewhere in Asia (Beniwal 1989; Gianno 1990). If uninfected trees had not been felled, the intensity of exploitation would have been reduced from $75 \%$ to $58 \%$. Further, if ambiguous trees contained no gaharu wood and felling was avoided, only $46 \%$ of trees would have been felled (Table 2). Wider use of known indicators to evaluate disease status prior to felling would enhance the sustainability of extraction in a managed system by increasing the number of reproductive adults in the residual population.

Although recovery of the Aquilaria population at Cabang Panti is uncertain, several factors point to a somewhat optimistic outlook. First, continued harvesting in the near future is unlikely because the low density of residual trees increases search time and decreases financial returns. Second, although reproductive adults are extremely rare in the residual population, continued reproduction may be possible because Aquilaria is monoecious (Hou 1960) and there is no published evidence of self-incompatibility. Third, felling Aquilaria trees has created light gaps that may, over time, promote growth of surviving regeneration near felled parents. In the regeneration plots placed randomly in lowland sandstone forest, the mean height of juveniles growing beneath open canopy in natural gaps ( $215 \pm 25 \mathrm{~cm}, n=59)$ was significantly higher than that of juveniles under partially closed or closed canopy (98 $\pm 15 \mathrm{~cm}, n=37$; Mann-
Whitney test, $U=525, p<0.001)$. Evidence of a positive response to light near felled trees was not present in the size structure of regeneration surveyed near trees (Fig. 3), but this sample was enumerated only months after light gaps were created by the 1991 harvest. Because gaps were small, gap colonization by fast-growing pioneer species that require large gaps is unlikely. Thus, over time, Aquilaria regeneration near harvested adults may respond well to localized high-light conditions created by felling the parent. Fourth, it may be possible to facilitate population recovery by initiating an enrichment planting program. Seedlings are abundant near felled and standing Aquilaria trees in lowland forest (Fig. 2), but our data suggest that in lowland sandstone forest juveniles may grow faster away from parents (Fig. 3 ), where conspecific densities are 200 times lower. Thus, transplanting seedlings from high-density patches near felled and standing trees to other sites in the forest, especially light gaps, may increase the growth-and possibly survivorship - of remaining seedlings.

\section{Economic Assessment}

Although it was short-lived, extraction of gaharu wood from Gunung Palung greatly increased the cash income of collectors. Estimated gross returns per day (\$8.80) were more than triple the daily village wage. Full-time gaharu-wood collectors undertook an average of 10 trips to Gunung Palung, generating a potential net income of $\$ 750$. This exceeded the national per capita gross domestic product by $85 \%$ in 1988 (International Monetary Fund 1990), the year most of the gaharu wood at Gunung Palung was harvested. Because local buyers extended credit for collection trips to any villager and many villagers participated, these benefits were distributed among many households. Income from gaharu wood enabled some collectors to continue educating their children and to build more durable homes. Rare but extremely valuable $A q u i$ laria trees, worth up to $\$ 7650$, generated exceptional profits of more than $\$ 3500$ per trip (Table 2) and attracted hundreds of collectors. Such high returns enabled some collectors to purchase land or capital equipment that greatly enhanced their income-earning capacity. Gaharu wood is no longer harvested from Gunung Palung, but it is currently harvested from remote regions of west and central Kalimantan.

Extraction was so profitable because collectors exploited a variety of forest types totaling more than 70,000 ha. If the estimated mean density of diseased trees at Cabang Panti $(0.14 / \mathrm{ha})$ is representative of the park, there were more than 9000 diseased trees in 1989, valued at nearly $\$ 700,000$ in net revenues. An estimated $92 \%$ of this value was liquidated, generating almost $\$ 640,000$ in profit distributed among hundreds of households in the region. 
An economic question of great importance to land-use planning in Kalimantan is whether gaharu-wood extraction in lowland forest generates financial returns per unit area higher than those of mechanized logging. Although profitable to collectors, gaharu-wood harvesting at Gunung Palung was so land-extensive that it generated a low potential net present value (Table 3). Reliable, published estimates of the net present value per hectare of mechanized logging in West Kalimantan are not available, but it likely exceeds that of gaharu wood by several orders of magnitude (L. M. Curran, unpublished data). Thus, establishing extractive reserves in Kalimantan for the sustainable harvest of gaharu wood at natural tree densities would not be favored over commercial logging on purely financial grounds.

\section{Management Potential of Gaharu Wood}

Gaharu wood is a tropical nontimber forest product with high potential for profitable extraction in a managed system because of its unusual economic and biological properties. It has an extremely high value per unit weight, it is nonperishable, and its major markets are international. Further, the tree's wide habitat distribution suggests that it could be cultivated on many soil types, especially on upland marginal soils where the frequency of gaharu-wood formation may be higher and competing land uses fewer. But the low density of diseased trees and long time interval between harvests would have to be manipulated in a managed system to increase the net returns per unit area.

Increasing the density of diseased trees in a managed system might be achieved by increasing both the overall density of trees and the percentage of trees that become infected. High-density stands of Aquilaria have been grown from nursery seedlings in plantation trials (Beniwal 1989), and natural gregarious stands in South Kalimantan (Sidiyasa et al. 1986) suggest that higher tree densities could be achieved through managed planting. A procedure for increasing the percentage of infected trees is widely used in India (Varschney 1991), where seedlings are raised in home nurseries, outplanted into high-light conditions, and then inoculated after 3 years by implanting recently harvested gaharu-wood nodules into the stem and lower branches. On average, trees can be felled 5 years later, producing gaharu wood on an 8 -year cycle. This cultivation method shortens the period between successive harvests and increases both the proportion of trees that yield gaharu wood and the yield per tree. In the Gunung Palung region, infected Aquilaria occur naturally, surviving regeneration is abundant, and some villagers have already begun planting and tending Aquilaria in forest gardens near their homes. Experimental trials to develop systems of small-scale cultivation are justified for this extremely valuable product.

\section{Acknowledgments}

This research was supported, in part, by the Program in Science and Technology Cooperation, Human Capacity Development; the Bureau for Global Programs, Field Support and Research; and the U.S. Agency for International Development (grant 9.249). Funding was also provided by the John Merck Fund and Conservation, Food and Health Foundation, Inc., to M.L. Additional support to G.D.P. was provided by a grant from the Carl and Lily Pforzheimer Foundation. We are grateful for the sponsorship of the Center for Research and Development in Biology (PPPB) of the Indonesian Institute of Sciences (LIPI) and the Subdirectorate of Nature Conservation of the Ministry of Forestry (PHPA) in Indonesia. In particular, D. Darnaedi and S. Wirjoatmodjo of PPPB-LIPI, T. Soehartono of PHPA, and K. Sebayang of LIPI greatly facilitated this research. We thank L. Curran, B. Furgeson, K. Glennemeier, A. Gorog, D. Lawrence, P. Stewart, V. Yates, and anonymous reviewers for helpful comments on earlier drafts of this paper.

\section{Literature Cited}

Anonymous. 1994. Fragrant black gold of Siberut Island. Rainforest Alliance Newsletter Fall:5-7.

Balick, M. J., and R. Mendelsohn. 1992. Assessing the economic value of traditional medicines from tropical rain forests. Conservation Biology 6:128-130.

Barber, C. V., N. C. Johnson, and E. Hafield. 1994. Breaking the logjam: obstacles to forest policy reform in Indonesia and the United States. World Resources Institute, Washington, D.C.

Beniwal, B. S. 1989. Silvical characteristics of Aquilaria agallocha. Indian Forester 115:17-21.

Bhattacharya, B., A. Dutta, and H. K. Baruah. 1952. On the formation and development of agaru in Aquilaria agallocha. Science and Culture 18:240-241.

Bodmer, R. E., T. G. Fang, and L. Moya. 1990. Fruits of the forest. Nature 343:109.

Bose, S. R. 1938. The nature of "agaru" formation. Science and Culture 4:89-91.

Browder, J. O. 1992. The limits of extractivism. BioScience 42:174-182.

Burkill, I. H. 1935. A dictionary of the economic products of the Malay Peninsula. 2 volumes. Crown Agents for the Colonies, London.

Clark, D. A., and D. B. Clark. 1984. Spacing dynamics of a tropical rain forest tree: evaluation of the Jazen Connell model. American Naturalist 124:769-788.

Dixon, J. A., and M. M. Hufschmidt. 1986. Economic valuation techniques for the environment: a case study workbook. Johns Hopkins University Press, Baltimore.

Fearnside, P. M. 1989. Extractive reserves in Brazilian Amazonia. BioScience 39:387-393.

Fong, F. W. 1992. Perspectives for sustainable resource utilization and management of Nipa vegetation. Economic Botany 46:45-54.

Gautier-Hion, A. J. D., R. Quiris, F. Feer, C. Saurd, and J. Decoux. 1985. Fruit characters as a basis of fruit choice and seed dispersal in a tropical forest vertebrate community. Oecologia 65:324-337.

Gianno, R. 1990. Semelai culture and resin technology. Connecticut Academy of Arts and Sciences, New Haven.

Gimlette, J. D. 1939. A dictionary of Malayan medicine. Oxford University Press, London.

Godoy, R., R. Lubowski and A. Markandya. 1993. A method for the 
economic valuation of non-timber tropical forest products. Economic Botany 47:220-233.

Gradwohl, J., and R. Greenburg. 1988. Saving the tropical forests. Earthscan Publications, London.

Grimes, A., S. Loomis, P. Jahnige, M. Burnham, K. Onthank, R. Alarcon, W. P. Cuenca, C. C. Martinez, D. Neill, M. Balick, B. Bennett, and R. Mendelsohn. 1994. Valuing the rain forest: the economic value of nontimber forest products in Ecuador. Ambio 23:405-410.

Hall, P., and K. Bawa. 1993. Methods to assess the impact of extraction of non-timber tropical forest products on plant populations. Economic Botany 47:234-247.

Hedge, R., S. Suryaprakash, L. Achoth, and K. S. Bawa. 1996. Extraction of non-timber forest products in the forests of Biligiri Rangan Hills, India. 1. Contribution to rural income. Economic Botany 50:243-251.

Hou, D. 1960. Thymeleaceae. Flora Malesiana. Series 1, volume 6 . Noordhoff-Kolff, Batavia.

Hou, D. 1964. Notes on some Asiatic species of Aquilaria (Thymeleaceae). Blumea 12:285-288.

International Monetary Fund. 1990. International financial statistics yearbook. IMF, Washington, D.C.

Jalaluddin, M. 1977. A useful pathogenic condition of wood. Economic Botany 31:222-224.

Kinnaird, M. F. 1992. Competition for a forest palm: use of Phoenix reclinata by human and nonhuman primates. Conservation Biology 6:101-107.

LaFrankie, J. V. 1994. Population dynamics of some tropical trees that yield non-timber forest products. Economic Botany 48:301-309.

MacBryde, B. 1994. CITES COP9 main results for plants. Biological conservation newsletter. National Museum of Natural History, Smithsonian Institution, Washington, D.C.

Mahindru, S. N. 1992. Indian plant perfumes. Metropolitan Press, New Delhi.

Murali, K. S., U. Shankar, R. U. Shaanker, K. N. Ganeshaiah, and K. S. Bawa. 1996. Extraction of non-timber forest products in the forests of Biligiri Rangan Hills, India. 2. Impact of NTFP extraction on regeneration, population structure and species composition. Economic Botany 50:252-269.

Nurhayanti, T. 1988. Siberut in the grip of gaharu fever. Voice of Nature. 4:8-13

O'Brien, T. G., and M. F. Kinnaird. 1996. Effect of harvesting on leaf development of the Asian plam Livistona rotundifolia. Conservation Biology 10:53-58.

Panayotou, T., and P. S. Ashton. 1992. Not by timber alone: economics and ecology for sustaining tropical forests. Island Press, Covelo, California.
Peluso, N. L. 1983. Markets or merchants? The East Kalimantan forest products trade in historical perspective. M. S. thesis, Cornell University, Ithaca, New York.

Peters, C. M., A. H. Gentry, and R. O. Mendelsohn. 1989. Valuation of an Amazonian rainforest. Nature 339:655-656.

Peters, C. P. 1990. Population ecology and management of forest fruit trees in Peruvian Amazonia. Pages 86-98 in A.B. Anderson, editor. Alternatives to deforestation: steps towards sustainable use of the Amazon raif forest. Columbia University Press, New York.

Plotkin, M. J., and L. M. Famolare. 1992. Sustainable harvest and marketing of rain forest products. Island Press, Washington, D.C.

Putz, F. E. 1992. Unnecessary rifts. Conservation Biology 6:301-302.

Salafsky, N., B. L. Dugleby, and J. W. Terbourgh. 1993. Can extractive reserves save the rain forest? Conservation Biology 7:39-52.

Schulze, P. C., M. Leighton, and D. R. Peart. 1994. Enrichment planting in logged rain forest: a combined economic and ecological analysis. Ecological Applications 4:581-592.

Schwartzman, S. 1989. Extractive reserves: the rubber tapper's strategy for sustainable use of the Amazon rain forest. Pages 150-165 in J. O. Browder, editor. Fragile lands of Latin America: strategies for sustainable development. Westview Press, Boulder, Colorado.

Shankar, U., K. S. Murali, R. U. Shaanker, K. N. Ganeshaiah, and K. S. Bawa. 1996. Extraction of non-timber forest products in the forests of Biligiri Rangan Hills, India. 3. Productivity, extraction and prospects of sustainable harvest of Amla, Phyllanthus emblica (Euphorbeaceae). Economic Botany 50:270-279.

Sidiyasa, K., S. Sutomo, and R. Prawira. 1986. Exploration and study of regeneration of "gaharu" producing species in Kintap forest region, South Kalimantan. Bulletin Penelitian Hutan 474:59-66.

Skeats, W. W. 1901. Malay magic: an introduction to the folklore and popular religion of the Malay Peninsula. Dover Press, New York.

Varschney, S. C. 1991. Production of liquid gold touches $15 \mathrm{~kg}$ per month. Indian Perfumer 35:10.

Wheatley, P. 1959. Geographical notes on some commodities involved in Sung maritime trade. Journal of the Malaysian Branch of the Royal Asiatic Society 32:5-139.

Whitkowski, E. T. F., B. B. Lamont, and F. J. Obbens. 1994. Commercial picking of Banksia bookeriana in the wild reduces subsequent shoot, flower and seed production. Journal of Applied Ecology 31:508-520.

Whitmore, T. C. 1973 . Thymelaeaceae. Pages 383-391 in T. C. Whitmore, editor. Tree flora of Malaya. Volume 2. Longman Press, Kuala Lumpur, Malaysia.

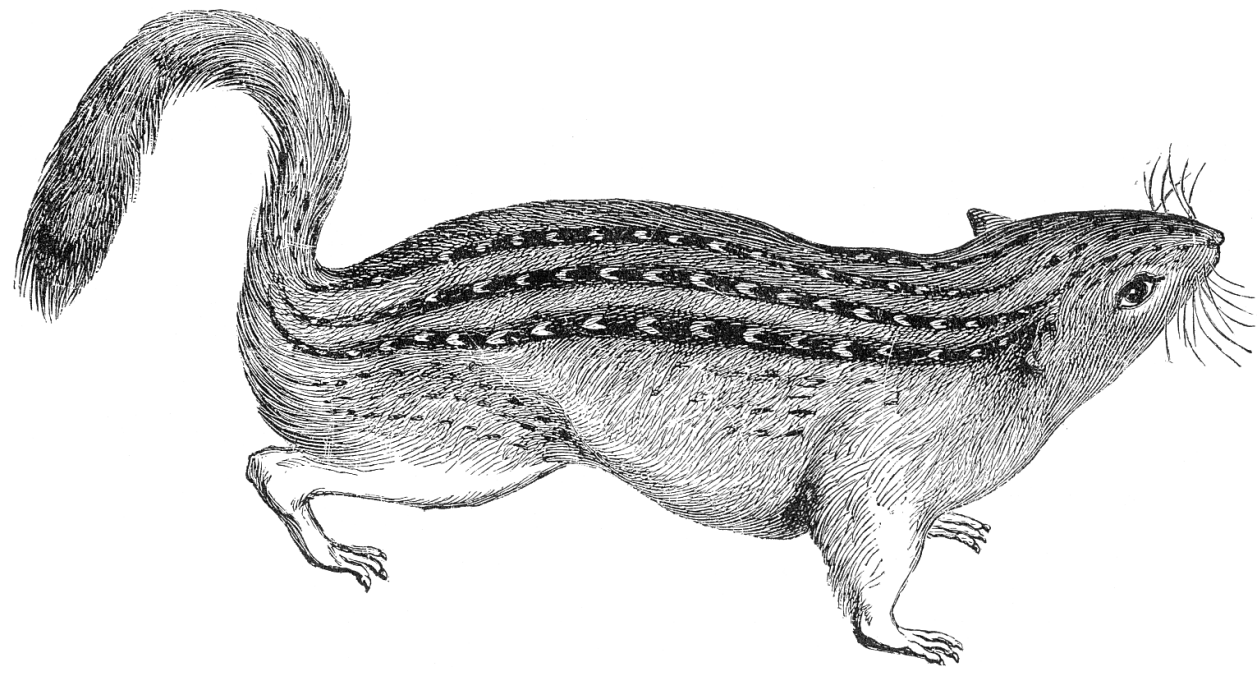

